\title{
Phronēsis in Antisthenes' Ajax and Odysseus
}

\section{Vladislav Suvák}

\begin{abstract}
The aim of this paper is to read Antisthenes' speeches Ajax and Odysseus from the perspective of "Socratic discourses", that is as a text which could represent an alternative form of the search for a good life. The putative theme of the speeches is the contest for the arms of Achilles. But readers can find at a deeper level another subject: Ajax and Odysseus show two moral characters involved in the debate over the correct meaning of excellence (aretē) or practical wisdom (phronēsis).
\end{abstract}

Keywords: Antisthenes' Ajax and Odysseus, aretē, phronēsis, Socratic dialogue, searching for a good life

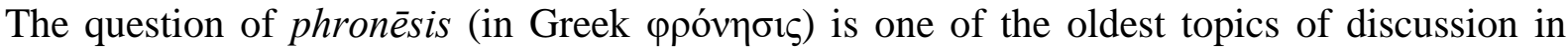
ancient ethics. We can translate the Greek word as "practical wisdom" or "prudence" (from the Latin prudentia). But neither of these modern terms is an accurate translation because phronēsis can also mean "human wisdom" or "mindfulness". For example, in Aristotle's Nicomachean Ethics phronesis is a type of practical wisdom which is distinguished from such other types of wisdom as technē, epistèmē or sophia.

Among the first-generation Socratics, phronēsis very soon became a synonym for the activity of a virtuous person (phronimos, spoudaios). It is likely that one of the first authors of "Socratic discourses" (logoi Sōkratikoi) was Antisthenes (cf. Giannantoni, 1990, pp. 345346). ${ }^{1}$ If one were to look for the earliest discussions about phronēsis in Greek philosophy, we would have to start with Antisthenes (cf. Brancacci, 2005). ${ }^{2}$ However, the situation is more complicated than it might seem. For one thing, no dialogues written by Antisthenes have actually been preserved. ${ }^{3}$ Although two speeches he authored are available in their entirety (Ajax and Odysseus), they resemble more closely epideictic declamations rather than Socratic dialogues in terms of genre. Other fragments more or less take the form of gnomes, apophthegms or chreias, and as such they are in fact based on later Cynic-Stoic genres (biography, apophthegmata etc.).

The aim of this paper is to read Antisthenes' speeches Ajax and Odysseus (SSR V A 53 and $S S R$ V A 54) as a text which could represent an alternative form of the Socratic search for a good life. The authenticity of the speeches has been much discussed in the past. ${ }^{4}$ Contemporary historians, however, and almost without exception, consider the speeches to be genuine. ${ }^{5}$ Ajax and Odysseus present a fictional rhetorical confrontation between well-known

\footnotetext{
${ }^{1}$ These authors of "Socratic discourses" - like Antisthenes, Aristippus, Euclid, Phaedo, Aeschines - were active in the first half of the $4^{\text {th }}$ century BC. For more details, see (Kahn, 1996, pp. 1-35).

2 Antisthenes' fragments are numbered in accordance with Giannantoni's edition (Giannantoni 1990, Vol. II, pp. 137-181); abbreviation SSR.

${ }^{3}$ Only short references to Antisthenes' dialogues and selected paraphrased passages have been preserved (Kahn, 1996, pp. 20, 33).

${ }^{4}$ F. W. A. Mullach described them as late imitations of Gorgias' speeches (Mullach, 1867, vol. II, pp. 269-270). L. Radermacher considered the speeches to be late prose transcriptions of an unknown tragedy of Ajax (Radermacher, 1892, pp. 569-576). Other classical philologists (Dahmen, 1897; von Arnim, 1898; Joël, 18931901; Lehnert, 1909; Wilamowitz-Moellendorff, 1912; Gomperz, 1922) have entered into the discussion to express slight or profound objections against the authenticity of the speeches.

${ }^{5}$ Cf. (Höistad, 1948); (Decleva Caizzi, 1966); (Patzer, 1970); (Rankin, 1986); (Giannantoni, 1990); (Brancacci, 1990); (Lévystone, 2005) etc.
} 
Homeric heroes. As the mythical background implies, the ostensible theme of the speeches is the contest for the arms of Achilles. But readers can find at a deeper level another subject. Ajax and Odysseus show two moral characters engaged in the debate over the correct meaning of excellence (aretē) or practical wisdom (phronēsis)

The older line of scholarly interpretation took Antisthenes' speeches as exemplary rhetorical exercises and placed them into a relationship with epideictic speeches of the type exemplified by Gorgias' Encomium of Helen. Friedrich Blass (Blass, 1892, pp. 310-315) was probably first to notice that these speeches also have a dialectical character. Historians turned their minds to a closer study of their content and became gradually convinced that Antisthenes depicted, through an ethical-rhetorical prism, his own understanding of human character (Höistad, 1948, pp. 94-102; Patzer, 1970, p. 213 etc.). Contemporary scholars, except for some minor exemptions (e.g. Luttazzo, 1996, pp. 275-357), agree that the speeches pose ethical questions. Many of these scholars are actually convinced that Antisthenes created them not under the influence of sophistical rhetoric, but as a Socratic. ${ }^{6}$ This means that we could or actually should read them in the context of Socratic thought. ${ }^{7}$

\section{Ajax in agōn}

The initial theme of Antisthenes' Ajax and Odysseus is a question of harmony between words (logoi) and deeds (erga) that is crucial to the definition of practical wisdom (phronessis). Both declamations deal with entitlement to Achilles' armour, as the two Homeric heroes defend themselves in an imaginary trial. Nonetheless, there is something else that gradually appears at the forefront: the speakers engage in a contest (agōn) over the correct definition of excellence (aretē), focusing their speeches on the actions they have previously taken individual deeds they consider excellent. It is exactly in the difference between words and deeds that we can identify two different approaches to wisdom (phronessis).

Right at the beginning of his speech, Ajax attacks the competence of the judges that have been appointed to judge his deeds (erga) on the basis of words (logoi), despite the fact that none of them witnessed the deeds with their own eyes. ${ }^{8}$ Regardless of the judges' incompetence, however, Ajax draws attention to Odysseus' past actions ("Odysseus had already profaned the sanctity of their temple by stealing the statue of Athena under cover of darkness") and future plans ("Odysseus asserts his right to [the armour] solely in order to sell it."), so as to undermine Odysseus' valour, which Odysseus likes to boast about (SSR V A 53, $\S 3, \S 6) .{ }^{9}$ In Ajax's opinion, Odysseus' cowardice is evident from the fact that he does not act directly - disguising his intentions and actions instead. ${ }^{10} \mathrm{He}$ does not mind gaining a bad reputation, which is something true soldiers would never allow (SSR V A 53, §5-6).

Ajax urges the judges not to take words into account in their decision-making and consider actions as far more important. It comes as a paradox, however, that he submits his request to those who, in his opinion, know nothing ( $S S R$ V A, 53 §7), which is why the judges cannot be competent (SSR V A 53, §1). There is an insurmountable ambiguity in Ajax's request, though: on the one hand, the Homeric hero cannot accept the fact that his actions are judged by someone who never witnessed them; on the other hand, he is at the mercy of inappropriate judges and asks them to take into account relevant actions rather than proclaimed words.

\footnotetext{
${ }^{6}$ Cf. (Patzer, 1970, pp. 246-255); especially the conclusion on p. 255: Der vorsokratische Antisthenes hat nie existiert ("The Presocratic Antisthenes never existed").

${ }^{7}$ Although Ajax and Odysseus are not Socratic dialogues, the two speeches are a valuable resource for those who study Antisthenes' way of thinking.

${ }^{8}$ Cf. SSR V A 53, §4.

${ }^{9}$ Translated by R. Dobbin (Dobbin, 2012).

${ }^{10}$ Ajax uses the opposition between lathra and phanerōs (secretly-evidently) to discredit Odysseus' courage because he acts in disguise (e.g. when he dresses up as a beggar). Odysseus answers Ajax' question in $\S 10$ of his speech (SSR V A 54).
} 
Nonetheless, he can only comment on his actions using words. Ajax's helplessness eventually results in a reckless suggestion that, rather than give an unfair verdict, the judges had better refrain from making a decision altogether. He even goes so far as to threaten the judges, warning them that they will be punished for any verdict that is unfair (SSR V A 53, §8).

In the final part of his speech, Ajax returns to his paradoxical request one more time, contrasting the truth that is based on actions with opinions that are based on words (SSR V A 53, §9): "I entrust you then to come to a determination about me and my actions; but I warn you all not to judge too hastily.","1

\section{Odysseus on his deeds}

Compared to Ajax's speech, Odysseus' speech is considerably longer and more balanced. It is addressed to the judges present in court as well as Odysseus' adversary. Odysseus stresses that it is only thanks to his actions that they do not have to suffer the misery and danger that come with war. ${ }^{12} \mathrm{He}$ responds to Ajax's accusations one by one, demonstrating they are all based on ignorance that he is unaware of. ${ }^{13}$ Ignorance (amathia) is like a disease that prevents man from desiring beautiful things (SSR V A, $54 \S 13)$ : "[I]gnorance is the greatest evil to those who have it."

In Odysseus' opinion, the cause of Ajax's erroneous judgement and conduct is his ignorance, even though it is unintentional (SSR V A 54, §4). ${ }^{14}$

Ajax thinks Odysseus is cowardly, but Odysseus shows how naïve Ajax's understanding of courage is. A soldier's excellence (aretē) does not consist in rushing to battle "in anger like a wild boar" ${ }^{15}$ Rather than toil in vain, which is of no use in a battle even if you act along with others, a soldier must use his wisdom, even if he should use it by himself. This is the type of person who will not be afraid of death: ${ }^{16}$ "[The] superior man avoids suffering of any kind whether he himself is the cause, or an associate, or an enemy soldier."17

At one point, Odysseus calls himself a protector who keeps an eye on all of his companions day and night, although they are unware of this. He uses this attribute to make his role stand out against the actions of the other Achaeans (SSR V A 54, §8). Odysseus is not afraid to use any weapons against his enemies - if need be, he does not hesitate to disguise himself as a slave, a beggar, a poor beaten soul. ${ }^{18}$ In Odysseus' opinion, such actions are

\footnotetext{
${ }^{11}$ Dobbin`s translation.

${ }^{12}$ SSR V A 54, $§ 1$. The motif of a "lone hero" is repeated several times; cf. SSR $§ \S 2-5 ; \S 14$.

${ }^{13}$ The way Odysseus tries to explain how Ajax made the false assumption resembles Antisthenes' conviction that contradiction is impossible (SSR V A 174). Odysseus stresses on several occasions that Ajax is "stupid" and "childish" (SSR V A $54 \S \S 6-7, \S 14)$. Odysseus' lecturing could be exemplified by the passage in which he relates Ajax's seeming courage to the circumstances of the battle and the Trojan customs (SSR V A 54, §§1112).

${ }^{14}$ Cf. Plato., Apol. 25d-26a, 37a. For more details on the Socratic nature of the Platonic thesis that ignorance is the cause of erroneous conduct, see Charles Kahn, who compares it to the argumentation of Antisthenes' Odysseus (Kahn, 1996, p. 92).

${ }^{15}$ SSR V A 54, §6. Cf. SSR V A 54, §13.

${ }^{16}$ SSR V A 54, §7. Cf. Plato., Apol. 41c-d; Charm. 173d), etc.

${ }^{17}$ SSR V A 54, §6. When he refers to the malign consequences of Ajax's wild anger, Odysseus points out that, above everything else, a good man controls his desires; cf. SSR V A 54, §5 (cf. the representation of Ajax's anger in period drama; Soph., Aj. 29, 47, 349, 461, 467, 511). In Antisthenean ethics, self-control (enkrateia) is one of the most important virtues of excellence. For Antisthenes, Odysseus is a prototypical Socratic wise man because he does not succumb to Circe's charms or give preference to Calypso over Penelope (cf. SSR V A 188): Odysseus does not believe in empty words, i.e. logoi without erga, because he knows that true immortality can only be earned through excellent deeds (erga).

${ }^{18}$ Rather than with weapons in the conventional sense of the word, Odysseus fights his enemy using all means possible; cf. $S S R$ V A 53, $\S 8$.
} 
examples of heroic deeds, too, although his fellow soldiers would not stoop so low (SSR V A 54, §9): "Whatever form of combat they choose I am always ready to meet them." 19

In the final part of his speech, Odysseus describes his own actions as wise, which might come across as rather immodest if it was not for Odysseus' explanation of what he means by wisdom: "I imagine that if ever there arises a poet who really knows what counts for excellence in a soldier, he will represent me as a clever, composed and resourceful combatant." 20

Odysseus' wisdom does not consist in the knowledge of or an insight into what is right; instead, it is based on finding ways of coping with the suffering and dangers of life in a sensible manner. Without the kind of wisdom that takes into account goals rather than majority opinions, Odysseus - along with his fellow Achaeans - would never have conquered Troy.

\section{Antisthenes' problematization of aretē}

Judging by the content and nature of his speeches, Antisthenes' speakers problematize the question of what excellence (aretē) means - a question that is based on an even older question related to the conflict over Achilles' armour: What does it mean to be the best Achaean? ${ }^{21}$ Antisthenes' reformulation of the original question and the way his heroes respond to it evidently suggest that Antisthenes adapts the mythical theme to the type of discussions that Socratic philosophers engaged in at the turn of the $5^{\text {th }}$ century BC.

Antisthenes' Ajax represents the traditional hero who is convinced that actions must precede words. ${ }^{22}$ However, he is not able to put his conviction into practice in a situation when the only criterion for judging actions that is to be met is giving a persuasive speech. Ajax is angry not only at Odysseus, but also at the judges who are to make a decision about his excellence. He contrasts the straightforwardness of his own behaviour with Odysseus' tendency to disguise his actions. However, Ajax's excellence can only be judged on the basis of the opinions of the handful of fellow soldiers who witnessed his actions. They are the only people he is answerable to - they are the only people who can judge his actions. The soundness of Ajax's conduct springs from the traditional understanding of a warrior's excellence which is actually substantiated in advance. A virtue that is defined in this way is then circumscribed by the warrior's actions, which make it meaningful, as well as the community of people who share Ajax's ideals.

In contrast to Ajax, Antisthenes' Odysseus represents a new type of hero - one who can harmonise his words with actions in all circumstances. Odysseus' excellence (aretē) or Odysseus' practical wisdom (phronessis) is not limited to the time of war. It is not difficult to imagine that his actions would have been just as successful in everyday life. Odysseus will not be controlled by anger like Ajax; instead, he can control his temper perfectly, which only proves that his words tally with his actions.

Several attributes suggest that Antisthenes sees Odysseus as the mythical prototype of a Socratic wise man (Giannantoni, 1990, Vol. IV, p. 263; Lévystone, 2005, p. 212). In Odysseus' opinion, a wise man ought to be able to come to terms with a bad reputation - just

\footnotetext{
${ }^{19}$ Dobbin's translation.

${ }^{20}$ Dobbin's translation. Odysseus predicts that one day a poet (as wise as Homer once was?) will praise his excellence and call him a man of much endurance, much intelligence, much contrivance (polutlanta kai polumetin kai polumēchanon). The three epithets start with the prefix polu- (much-), possibly referring to the polytropic, multi-trait nature of Odysseus' personality, as a result of which he comes across as not only rhetorically skilful, but also ethically excellent in the Socratic sense (cf. SSR V A, 187).

${ }^{21}$ SSR V A 53, §4, §6, §7, §11 (“judging about virtue”). Cf. (Nagy, 1979, pp. 22-25, 43-49).

${ }^{22}$ Ajax emphasises the status of a true soldier in the final part of his speech (SSR V A 53, §9): “....and me on the other hand, always the first in line for battle, unattended, and outside the protection of the fortress walls."
} 
as Socrates comes to terms with the accusations that he has a malign influence on young men living in Athens and does not believe in the gods of the city. ${ }^{23}$ In the same spirit, Antisthenes figured in doxographic testimony claims that man must be indifferent to the opinions of others. ${ }^{24}$ At one point in his speech, Odysseus lectures Ajax, explaining that ignorance is like a disease that a person is unaware of - an ignorant person does not deserve our condemnation but our pity ( $S S R$ V A 54, §4-5). Odysseus claims to be a guardian of the ignorant - the unknowing who cannot use their brains as an effective weapon. What prevents them from acting in accordance with reason and recognising Odysseus' actions as reasonable are mere prejudices. Odysseus is a guardian who protects his companions from both enemies and themselves (SSR V A 54, §8): "Like sea captains who personally attend to the safety of their crew, night and day, I look after your welfare and everyone else's besides." 25

It is in this role that Odysseus primarily resembles Socrates, who describes himself as a tireless inquirer who helps himself and others take care of themselves (eautou epimeleia). ${ }^{26}$

Understood as a disease of the soul, ignorance (amathia) is one of the key themes of Socratic philosophy. ${ }^{27}$ Antisthenes puts ignorance in the Socratic context when he has Odysseus criticise Ajax for succumbing to public opinion on what is right and good. ${ }^{28}$ A good person can tolerate no evil - not in a friend, not in an enemy, not in themselves. Odysseus' statement echoes Socrates' belief that nothing bad can happen to a good person. ${ }^{29}$ Although involuntary, Ajax's ignorance is, in Odysseus' opinion, the cause of his erroneous judgment and conduct. ${ }^{30}$ Whether Ajax can be cured of his pathological state of mind depends on his willingness to listen to Odysseus without strong emotions, rationally considering the motives of his own behaviour at the same time. Odysseus' lecturing is exemplified by distinguishing between physical, bodily strength (ischus) and courage (andreia), which is a type of knowledge (epistemene or sophia). ${ }^{31}$ Ajax is a classic example of a courageous man whose ability (dunamis) comes from his passion (which is why he is so prone to succumb to madness), but he is not courageous or bold because courage requires a rational control of passions. ${ }^{32}$ In a similar spirit, Antisthenes describes Alcibiades, who was not just handsome and happy to take chances, but also "violent and a man with no upbringing or education whatsoever." "33 The key word in Athenaeus' report is the adjective "badly educated" or "uneducated" (apaideutos) because courage becomes a virtue only thanks to practical wisdom, which requires a "Socratic strength" (Dudley, 1990, p. 11). At this point, it is worth getting back to the subheading of Antisthenes' treatise called The Greater Heracles, namely "on Strength" (Peri ischuos). Besides ischus, the alternative title also included the term phronēsis ("practical wisdom"): Hêraklēs hē peri phronēseōs hē ischuos (Heracles, or on

\footnotetext{
${ }^{23}$ Cf. Plato., Apol. 18c.

${ }^{24}$ Cf. Diog. Laert. VI 11: "ill repute is a good thing".

25 Dobbin`s translation. In this sense, Odysseus explains to Ajax that his ignorance prevents him from recognising all the good things that Odysseus has provided him with (SSR V A 54, §4).

${ }^{26}$ For more details on Socrates' mission, see Plato., Apol. 31b: "I have neglected all my own affairs and have been enduring the neglect of my concerns all these years, but I am always busy in your interest, coming to each one of you individually like a father or an elder brother and urging you to care for virtue." Translated by $\mathrm{H}$. N. Fowler (Plato, 1914).

${ }^{27}$ Cf. Plato., Euthyd. 281e4-5; see also Alcib. II. 148a; Tim. 88b; Phil. 49a; Xenoph., Mem. III 9,4, etc.

${ }^{28}$ Cf. SSR V A 54, §§3-6.

${ }^{29}$ Cf. Plato., Apol. 41c-d. For more details, see (Lévystone, 2005, p. 185); (Montiglio, 2011, pp. 28-29).

${ }^{30}$ Cf. Plato., Apol. 25d-26a, 37a for more details on the difference between voluntary and involuntary conduct that Plato reformulates in his subsequent dialogues into the well-known paradox that no man voluntarily pursues evil. For more details, see (Kahn, 1996, p. 92).

${ }^{31}$ Cf. Plato., Prot. 350d-e.

${ }^{32}$ Cf. Plato., Prot. $351 \mathrm{a}$.

${ }^{33}$ Athen. XII 534 C [= SSR V A 198].
} 
Practical Wisdom or on Stregth). ${ }^{34}$ Allegedly, the main theme of the dialogue would have been Socrates' perseverance as a representation of phronēsis, i.e. ethical excellence embodied and personified by the mythical Heracles (Höistad, 1948, p. 36) ${ }^{35}$ This prototype of a Socratic wise man might have also applied to Odysseus - a hero who can be reasonable in any situation.

Odysseus' wisdom does not only make his own life better, but it also helps improve the lives of those who are willing to listen to him and think about themselves. In this sense, Odysseus is the steersman, guardian, and healer of ignorant people - he can cure them of the greatest disease that our souls can suffer from, i.e. ignorance (amathia). Antisthenes' Odysseus is an embodiment or the kind of practical wisdom and spiritual strength without which we cannot take care of our own lives. We all need Odysseus, we all need Heracles, and, most of all, we all need Socrates - provided that we want to learn to live our lives wisely and happily. Furthermore, they need us, as living our life wisely requires continual examination, effort, and toil. Wisdom by itself is not enough for a person to be cured of ignorance.

\section{Conclusion}

The purpose of Socratic education is to give the life of an individual a sense of direction, turning it into something beautiful and good. ${ }^{36}$ The key virtue or excellence (aretē) in this effort is practical wisdom. Our reconstruction of Antisthenes' understanding of practical wisdom (phronēsis) suggests that early Socratic philosophers struggled to grasp the notion. Antisthenes' concept of wisdom is an alternative to the way Plato understands the notion. Antisthenes links wisdom with endurance and self-control - with an asceticism that results in excellent decisions. Antisthenes draws on the Socratic conviction that only thanks to practical wisdom can we distinguish between things that are deceptive with regard to life and those that are actually beneficial. The therapeutic function of wisdom (phronesis) consists in eliminating all deceptive assumptions about what it means to live a good life. If we desire pleasures or if we long for wealth and power, we will soon become slaves to our own desires. However, wisdom by itself is not enough for anyone to live a happy life. Wisdom requires Socratic education, i.e. instruction aimed at others as well as ourselves. Without Socrates, i.e. without receiving help from someone who helps others through mutual love, we cannot give our lives the right direction.

\section{Acknowledgement}

This paper is a part of research project VEGA, No. 1/0017/17, Aeschines and the Socratic dialogue.

Vladislav Suvák is Associate Professor of Philosophy. He obtained his doctorate from Comenius University in Bratislava (2000). Currently he works as a senior lecturer in the history of philosophy at the Institute of Philosophy, Prešov University. His research focuses on ancient philosophy (Sophist and Socratics), ancient ethics (Antisthenes, Diogenes of Sinope, Cynicism) and its reflection (Nietzsche, Heidegger, Foucault). Selected publications:

\footnotetext{
${ }^{34}$ Cf. SSR V A 41.

35 All ancient resources that associate ischus with Antisthenes' Heracles and Cyrus date back to a later doxographic tradition. However, their credibility can be supported by selected passages from Antisthenes' Odysseus, in which Odysseus explains that Ajax' errors of conduct were all caused by ignorance.

${ }^{36}$ As a model of Socratic education, cf. the argumentation in Aeschines' Alcibiades (SSR VI A 53): while doctors treat the ill thanks to a human art, Socrates is beneficial to those who need what he has to offer thanks to a gift from the gods - Socrates says: "Just so I have no knowledge of any subject that I can benefit a person by teaching him, and yet I thought that by being with him I would make him better, through my loving him." Translated by G. Boys-Stones and C. Rowe (Boys-Stones \& Rowe, 2013).
} 
Cepko, J., Kalaš, A., Suvák, V., Diogenis fragmenta / Diogenove zlomky, Bratislava 2016 (The Fragments of Diogenes of Sinope); Suvák, V. (ed.), Antisthenica Cynica Socratica, Prague 2014; Kalaš, A., Suvák, V., Antisthenis fragmenta / Antisthenove zlomky, Bratislava 2013 (The Fragments of Antisthenes of Athens); Sokratika: Štyri štúdie k sókratovskej tradicii myslenia, Prešov 2007 (Socratics: Four studies concerning the Socratic Movement).

\section{Corresponding author:}

Vladislav Suvák, Institute of Philosophy, University of Prešov, 17. novembra 1, SK-08078 Prešov (Slovakia)

Email: vladislav.suvak@gmail.com

\section{References}

ARNIM, H. von (1898): Leben und Werke des Dio von Prusa. Berlin: Weidmann.

BLASS, F. (1892): Die attische Beredsamkeit, vol. 3. Leipzig: Teubner.

BOYS-STONES, G. \& ROWE, C. (2013): The Circle of Socrates: Readings in the FirstGeneration Socratics. Indianapolis: Hackett Publishing Co.

BRANCACCI, A. (1990): Oikeios Logos: La filosofia del linguaggio di Antistene. Napoli: Bibliopolis.

BRANCACCI, A. (2005): Episteme and Phronesis in Antisthenes. In: Méthexis, 18(1), pp. 728.

DAHMEN, J. (1897): Quaestiones Xenophonteae et Antistheneae. Diss. Berlin.

DECLEVA CAIZZI, F. (ed.) (1966): Antisthenis Fragmenta. Documenti per lo Studio dell'Antichità XIII. Milano: Istituto Editoriale Cisalpino

DOBBIN, R. (ed.) (2012): The Cynic Philosophers from Diogenes to Julian. London: Penguin Books.

DUDLEY, D. R. (1990): A History of Cynicism: From Diogenes to the Sixth Century A.D. Chicago: Ares.

GIANNANTONI, G. (ed.) (1990): Socratis et Socraticorum Reliquiae, 4 vol. Napoli: Bibliopolis.

GOMPERZ, H. (1922): Griechische Denker II: Sokrates und die Sokratiker. Plato und die Alte Akademie. Berlin \& Leipzig: Vereinigung wissenschaftlicher Verleger.

HÖISTAD, R. (1948): Cynic Hero and Cynic King: Studies in the Cynic Conception of Man. Lund: Carl Bloms Boktryckeri.

JOËL, K. (1893-1901): Der echte und der Xenophontische Sokrates, 2 vol. Berlin: R. Gaertners Verlagsbuchhandlung.

KAHN, C. H. (1996): Plato and the Socratic Dialogue. Cambridge: Cambridge University Press.

LEHNERT, G. (1909): Bericht über die rhetorische Literatur bis 1906. In: W. Kroll (ed.): Jahresbericht über die Fortschritte der classischen Altertumswissenschaft. Leipzig: Altitalische Sprachdenkmäler, pp. 226-340.

LÉVYSTONE, D. (2005): La figure d'Ulysse chez les Socratiques: Socrate polutropos. In: Phronesis, 50(3), pp. 181-214.

LUTTAZZO, M. T. (1996): Dialettica o retorica? La polytropia di Odisseo da Antistene a Porfirio. In: Elenchos, 17(2), pp. 275-357.

MONTIGLIO, S. (2011): From Villain to Hero: Odysseus in Ancient Thought. Ann Arbor, MI: The University of Michigan Press

MULLACH, F. W. A. (ed.) (1867): Fragmenta philosophorum graecorum. Collegit, recensuit, vertit annotationibus et prolegomenis illustravit indicibus, 3 vol. Parisiis: Editore Ambrosio Firmin Didot. 
NAGY, G. (1979): The Best of the Achaeans. Baltimore: Johns Hopkins University Press.

PATZER, A. (1970): Antisthenes der Sokratiker. Das literarische Werk und die Philosophie, dargestellt am Katalog der Schriften. Heidelberg (dissertation thesis).

PLATO (1914): Euthyphro, Apology, Crito, Phaedo, Phaedrus, trans. by H. N. Fowler. Cambridge, MA: Harvard University Press.

RADERMACHER, L. (1892): Der Aias und Odysseus des Antisthenes. In: Rheinisches Museum für Philologie, 47, pp. 569-576.

RANKIN, H. D. (1986): Antisthenes Sokratikos. Amsterdam: Hakkert.

WILAMOWITZ-MOELLENDORFF, U. von (1912): Die griechische Literatur des Altertums. Stuttgart: Teubner. 